\title{
Hepatotoxicity and nephrotoxicity of 3-bromopyruvate in mice ${ }^{1}$
}

\author{
Qiong Pan', Yiming Sun", Qili Jin ${ }^{\mathrm{III}}$, Qixiang Li' ${ }^{\mathrm{IV}}$, Qing Wangv, Hao Liu ${ }^{\mathrm{VI}}$, Surong Zhao ${ }^{\mathrm{VII}}$ \\ DOI: http://dx.doi.org/10.1590/S0102-865020160110000004 \\ IGraduate student, Department of Pharmacy, China. Technical procedures, manuscript preparation.

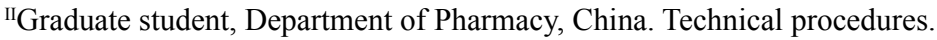 \\ IIIAssistant Professor, Department of Pathology, China. Technical procedures. \\ ${ }^{\text {IV }}$ Graduate student, Department of Pharmacy, China, Technical procedures. \\ ${ }^{v}$ Assistant Professor, Department of Pharmacy, China. Conception and design of the study, critical revision. \\ ${ }^{\mathrm{V}}$ Full Professor, Department of Pharmacy, China. Conception and design of the study. \\ ${ }^{\mathrm{VII}}$ Assistant Professor, Department of Pharmacy, China. Conception and design of the study, critical revision.
}

\begin{abstract}
PURPOSE: To investigate the hepatotoxicity and nephrotoxicity of 3-Bromopyruvate (3BP) in mice.

METHODS: Fifteen nude mice were grafted subcutaneously in the left flank with MDA-MB-231 cells, then all mice were divided into control group (PBS), 3BP group ( $8 \mathrm{mg} / \mathrm{kg}$ ), positive group (DNR: $0.8 \mathrm{mg} / \mathrm{kg}$ ) when tumor volume reached approximately $100 \mathrm{~mm}^{3}$. 28 days later, tumors, livers and kidneys were stored in $4 \%$ formalin solution and stained with hematoxylin and eosin staining. The Kunming mice experiment included control group (PBS), 3BP group (4mg/kg; 8mg/kg; 16mg/kg), positive group (DNR: $0.8 \mathrm{mg} / \mathrm{kg}$ ). 24 hours later, the blood were used for the determination of hepatic damage serum biomarkers. Livers were stored in $4 \%$ formalin solution for the later detection.
\end{abstract}

RESULTS: $3 \mathrm{BP}$ at the dose of $8 \mathrm{mg} / \mathrm{kg}$ had a good effect on inhibiting tumor growth in nude mice and did not damage liver and kidney tissues. Kunming mice experiment showed 3BP at the dose of $16 \mathrm{mg} / \mathrm{kg}$ did damage to liver tissues.

CONCLUSION: 3-Bromopyruvate at the dose of suppressing tumor growth did not exhibit hepatotoxicity and nephrotoxicity in nude mice, and the effect on liver was confirmed in Kunming mice.

Key words: Bromopyruvate. Hepatotoxicity. Nephrotoxicity. Mice 


\section{Introduction}

Cancer cells acquire energy mainly through the glycolytic pathway rather than oxidative phosphorylation, while the normal cells depend mainly on mitochondrial oxidative phosphorylation to get energy, this particular phenomenon is called "Warburg effect" $\left\{\right.$ Geschwind, 2002 \#5\} \{Geschwind, 2002 \#5\} Warburg ${ }^{1}$. Thus, we can inhibit the growth of tumor cells by inhibiting glycolytic pathway ${ }^{2}$. As a glycolytic inhibitor, “3BP is a fast acting, promising, powerful, specific and effective anti-cancer agent", said by Pedersen ${ }^{3}$. Also 3BP has been identified to inhibit tumor cells proliferation as a proposed widely used anti-cancer agent ${ }^{4}$, such as in breast cancer cells ${ }^{5,6}$, liver cancer cells ${ }^{7,8}$, lymphoma cells ${ }^{9}$, lung cancer cells ${ }^{10}$, pancreatic cancer cells ${ }^{11,12}$, gastric cancer ${ }^{2,13}$, colorectal cancer cells ${ }^{14}$. Those significant anti-tumor effects of 3BP has made it getting more and more attention ${ }^{15,16}$.

Our group also pay attention to the anti-tumor activity of 3BP. For one paper, 3BP induced autophagy by stimulating ROS formation in human breast cancer cells, which could be inhibited by chloroquine ${ }^{17}$. The further research demonstrated that 3BP could induce apoptosis via AKT / protein kinase B signaling in breast cancer cells MDA-MB-231, and the knockdown of Mcl-1 plays an important role in 3BP-induced apoptosis ${ }^{18}$. Also, 3BP efficiently enhanced DNR-induced cytotoxicity in breast cancer cells by inhibiting the activity of ATP, especially, MCT1 overexpression increased the efficacy of 3BP in breast cancer cells MDA-MB-2316. Recently, we found that 3BP could also induce necroptosis and apoptosis at the same time and the same concentration in colon cancer cells SW480 and HT2914.

Toxicity is one of problems that must be considered during the treatment of disease. It correlates with excessive drug-dose or too long drug treatment for the body. Drug-related hepatotoxicity of some drugs has been defined in literature. Acetaminophen is the most widely used antipyretics, which is a safe drug at therapeutic doses. However, its overdose can lead to hepatic and renal damage ${ }^{19}$, which may be fetal. Ifosfamide is an anti-cancer agent, which is widely used in the treatment of solid tumors, such as gynecologic, head and neck cancers, lymphomas, and osteogenic sarcoma ${ }^{20}$, but the nephrotoxicity particularly limited its application ${ }^{21,22}$.

Though previous research showed that 3BP had no hepatotoxicity when inhibiting lung tumor genesis ${ }^{10}$. Whether $3 \mathrm{BP}$ is safe in other tumors is still a pending issue. In the work here we focus on hepatotoxicity and nephrotoxicity of 3BP in nude mice and Kunming mice.

\section{Methods}

This study was approved by the Ethics Committee of Bengbu Medical College.

The compound 3BP was purchased from Sigma-Aldrich (St. Louis, MO, USA). Daunorubicin (DNR) was obtained from Zhejiang Hisun Pharmaceutical Company Limited (Zhejiang, China). One step TUNEL apoptosis assay kit was purchased from Beyotime Institute of Biotechnology (Wuhan, China). Solution of 3BP was prepared in phosphate-buffered saline (PBS), after adjusting the $\mathrm{pH}$ to 7.0 with $\mathrm{NaHCO}_{3}$ the solution was sterilized with $0.22 \mu \mathrm{m}$ Millipore filter before immediate use.

Fifteen female nude mice (BALB/c) aged 4-5 weeks and weighed 18-20 g were used in this study, which were purchased from Suzhou Industrial Park, Ireland Matt Technology Co. Ltd. All mice were injected with human breast cells MDA-MB-231 $\left(10^{8}\right.$ cells $\left./ \mathrm{ml} ; 0.2 \mathrm{ml} / \mathrm{mouse}\right)$ subcutaneously to induce tumor formation, then they were randomly divided into three groups $(\mathrm{n}=5$ per group) when tumor volume reached approximately 100 $\mathrm{mm}^{3}$ : control group, drug group and positive group, which were intraperitoneally injected every second day with $0.2 \mathrm{ml}$ of PBS, 3BP $(8 \mathrm{mg} / \mathrm{kg})$ and DNR $(0.8 \mathrm{mg} / \mathrm{kg})$ for 28 days, then the mice were sacrificed after quickly removing blood, liver and kidney for the subsequent analysis.

Twenty-five Kunming mice $(18-20 \mathrm{~g})$ were obtained from the Experiment Center of Bengbu Medical College. All animals were divided into four groups: control group (PBS; 0.2ml), drug group (3BP; $4 \mathrm{mg} / \mathrm{kg}$, $8 \mathrm{mg} / \mathrm{kg}, 16 \mathrm{mg} / \mathrm{kg}$ ), positive group (DNR $0.8 \mathrm{mg} / \mathrm{kg}$ ), which were treated with single intraperitoneal injection, 24 hours later, blood and liver were collected for the subsequent analysis.

All animals were kept at room temperature and subjected to a natural day/night light cycle and allowed free access to standard diet and water.

\section{Blood chemistry analysis}

Animals were sacrificed after quickly removing liver and kidney, and blood were collected from eyes. The samples of blood were stewing for half an hour, taking the upper serum after centrifugation $(1500 \mathrm{r} / \mathrm{m}, 10 \mathrm{~min})$. The serum was detected by automatic biochemical analyzer (Beckman, USA).

\section{Hematoxylin and eosin staining assay}

Tumors, livers and kidneys were stored in $4 \%$ formalin 
solution, embedded in paraffin, which were cut into sections and stained with hematoxylin and eosin according to the manufacturer's instructions.

\section{Immunohistochemistry assay}

Liver tissues were stored in $4 \%$ formalin solution, embedded in paraffin, which were cut into tissue sections and were used for immunohistochemistry according to the manufacturer's instructions.

\section{TUNEL assay}

The slices of liver tissues were stored in $4 \%$ formalin solution, embedded in paraffin, which were cut into sections and were analyzed by one step TUNEL apoptosis assay kit. The analysis was carried out according to the manufacturer's instructions.

\section{Statistical analysis}

All data were expressed as mean \pm standard deviation (SD). SPSS v.16.0 software (SPSS Inc., Chicago, IL, USA) was used for data analysis. ${ }^{*} \mathrm{p}<0.05$ was considered statistically significant.

\section{Results}

\section{The effect of $3 B P$ in nude mice}

3BP clearly suppressed tumor growth compared with the control group (Figure $1 \mathrm{a}, \mathrm{b}$ ). The results of H\&E staining demonstrated that 3BP caused part of necrosis tumor issues (Figure 1c). The analysis of blood chemistry showed that activity of AKP, ALT and AST changed indistinctively ( $p>0.05)$, which means that $3 \mathrm{BP}$ at $8 \mathrm{mg} / \mathrm{kg}$ did not damage liver tissues (Figure 2a), also the same results of H\&E staining on liver (Figure 2b). The analysis of blood chemistry in nude mice showed that the concentration of BUN, UA and CER changed indistinctively ( $p>0.05)$, which means that $3 \mathrm{BP}$ at $8 \mathrm{mg} / \mathrm{kg}$ did not damage significantly to kidney tissues (Figure 2c). The results of H\&E staining showed that 3BP at $8 \mathrm{mg} / \mathrm{kg}$ did not damage kidney tissues (Figure $2 \mathrm{~d}$ ).
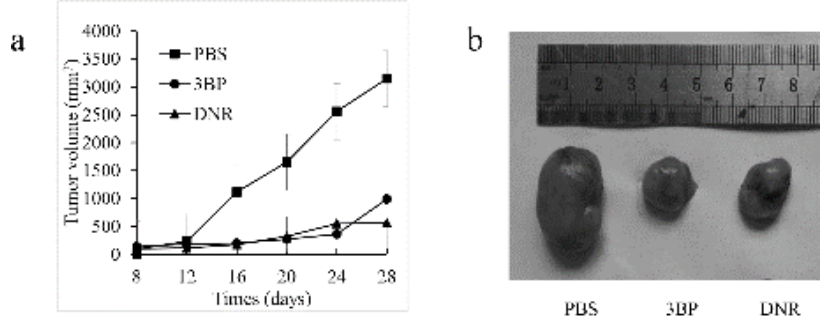

$\mathrm{c}$
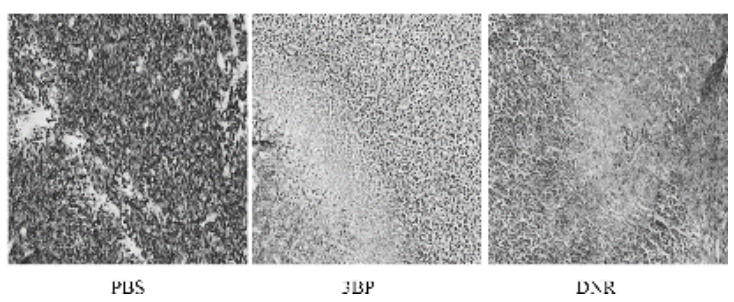

FIGURE 1 - Antitumor effect of 3BP in nude mice. Breast cancer cells MDA-MB-231 were inoculated subcutaneously to induce tumor formation. Mice with tumors $\left(100 \mathrm{~mm}^{3}\right)$ were randomly divided into three groups (5 mice/group). The tumor volume was calculated from day 8 . a. Comparison of tumor volumes. Tumor growth was monitored every 4 days and calculated with the formula: length $\mathrm{x}$ width ${ }^{2} / 2$. b. Comparison of the transplanted tumor. Tumors were quickly removed after animals were sacrificed, take a photograph of them for comparison. c. H\&E staining of tumor tissues in vivo. $3 \mathrm{BP}$ at $16 \mathrm{mg} / \mathrm{kg}$ caused part of necrosis tumor issues compared with the control group.
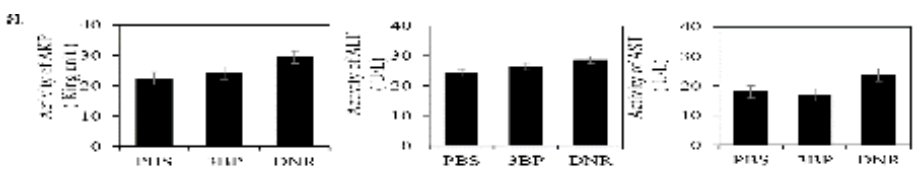

b
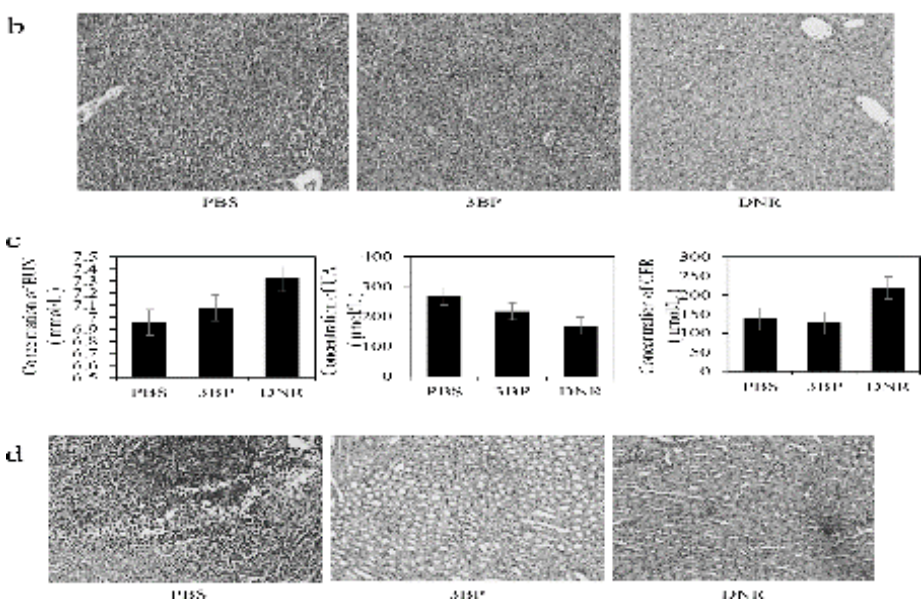

FIGURE 2 - The effect of 3BP on liver and kidney in nude mice. The analysis of blood chemistry indicator. The blood was collected from animal eyes. The samples of blood were stewing for half an hour, taking the upper serum after centrifugation $(1500 \mathrm{r} / \mathrm{m}, 10 \mathrm{~min})$, then analyzed by automatic biochemical analyzer. a. The analysis of the activity of AKP, ALT and AST in serum changed indistinctively in drug groups compared with the control group $(\mathrm{p}>0.05)$. b. H\&E staining of liver tissues in vivo. $3 \mathrm{BP}$ at $8 \mathrm{mg} / \mathrm{kg}$ caused no hepatotoxicity compared with the control group. c. The concentration of BUN, UA and CER in serum changed indistinctively $(\mathrm{p}>0.05)$. d. H\&E staining of kidney tissues in vivo. 3BP at $8 \mathrm{mg} / \mathrm{kg}$ caused no nephrotoxicity compared with the control group. 


\section{The effect of $3 B P$ on liver and kidney in Kunming mice}

Liver index in drug groups were higher $(p>0.05)$ than that in control group (Figure 3a).The activity of AST and ALT both increased in three drug groups, 3BP at $4 \mathrm{mg} / \mathrm{kg}$ and $8 \mathrm{mg} /$ $\mathrm{kg}$ did not change significantly ( $>00.05$ ), while $3 \mathrm{BP}$ at $16 \mathrm{mg} / \mathrm{kg}$ group changed significantly $(\mathrm{p}<0.05)$ compared with the control group (Figure $3 b$ ). The results of H\&E staining showed that 3BP at $8 \mathrm{mg} / \mathrm{kg}$ did not make damage to liver tissues (Figure 3c). As an endoplasmic reticulum stress protein, the expression of GAPDH will be increased when tissues were injured. Compared with the control group, the expression of GAPDH at $4 \mathrm{mg} / \mathrm{kg}$ and $8 \mathrm{mg} /$ $\mathrm{kg}$ 3BP group did not changed obviously, while its expression in $16 \mathrm{mg} / \mathrm{kg} 3 \mathrm{BP}$ group (Figure 3d). The result of TUNEL assay showed that there were few apoptotic cells in $4 \mathrm{mg} / \mathrm{kg}$ and $8 \mathrm{mg} / \mathrm{kg}$ $3 \mathrm{BP}$ group, while more apoptotic cells could be seen in $16 \mathrm{mg} / \mathrm{kg}$ 3BP group and positive group (Figure 3e).

These results indicated that $3 \mathrm{BP}$ at the dose of suppressing tumor growth did not exhibit hepatotoxicity and nephrotoxicity in nude mice.

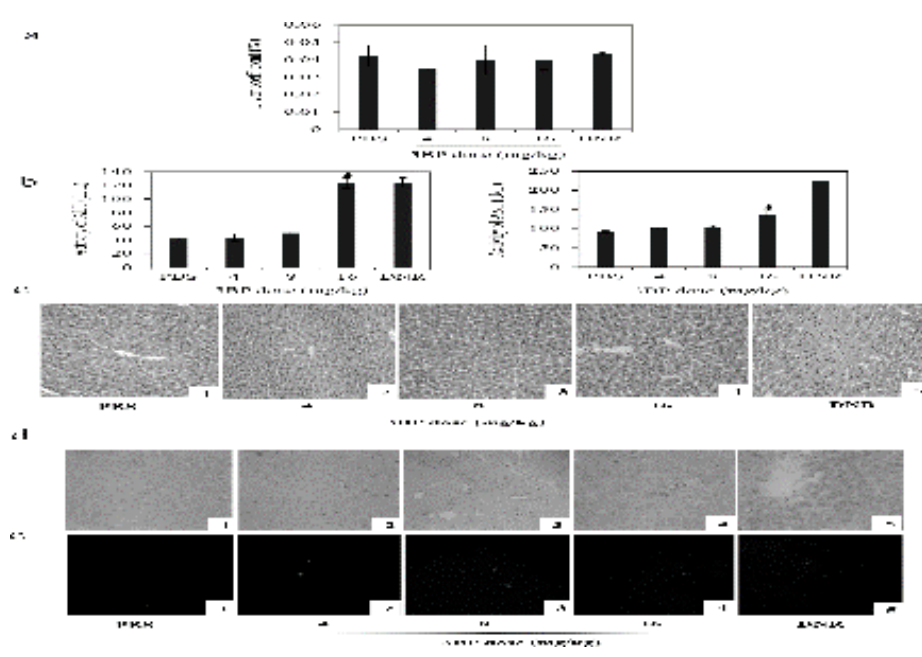

FIGURE 3 - The effect of 3BP on liver in Kunming mice. a. Comparison of liver index. Liver was collected after animals were sacrificed and were calculated with the formula: liver index weight/body weight $\times 100 \%$. Liver index in 3BP $(4 \mathrm{mg} / \mathrm{kg})$ group were higher compared with the control group ( $>00.05)$. With the increasing drug dose, the liver index in 3BP $(8 \mathrm{mg} /$ $\mathrm{kg})$ group and $3 \mathrm{BP}(16 \mathrm{mg} / \mathrm{kg})$ group was almost equal. b. Comparison of activity of ALT and AST in serum increased in drug groups, 3BP at $4 \mathrm{mg} /$ $\mathrm{kg}$ and $8 \mathrm{mg} / \mathrm{kg}$ did not change significantly compared with the control group $(\mathrm{p}>0.05)$, while $3 \mathrm{BP}$ at $16 \mathrm{mg} / \mathrm{kg}$ group changed significantly $(\mathrm{p}<0.05)$. c. $\mathrm{H} \& \mathrm{E}$ staining of liver tissues in vivo. $3 \mathrm{BP}$ at $4 \mathrm{mg} / \mathrm{kg}$ and $8 \mathrm{mg} /$ $\mathrm{kg}$ did not cause hepatotoxicity compared with the control group. d. The effect of 3BP on expression of GAPDH in liver. The expression level of GAPDH at $4 \mathrm{mg} / \mathrm{kg} 3 \mathrm{BP}$ and $8 \mathrm{mg} / \mathrm{kg}$ 3BP group changed fairly compared with control group. e. The effect of $3 \mathrm{BP}$ on apoptosis. There were few apoptotic cells in $3 \mathrm{BP}$ at $4 \mathrm{mg} / \mathrm{kg}$ and $8 \mathrm{mg} / \mathrm{kg}$ group, while $16 \mathrm{mg} / \mathrm{kg}$ group were changed significantly compared with the control group.

\section{Discussion}

As a glycolytic inhibitor, 3BP has been widely used in anti-cancer researchers in various tumor cells ${ }^{9}$, particularly in liver cancer cells ${ }^{23}$. Our group have done some researches about 3BP anti-tumor effect in vivo ${ }^{18}$. The researches of anti-cancer effects of 3BP had a good foundation of papers. However, there were few researches about the toxicity of 3BP.

Liver is the major organ to cope with metabolic substances, which has various functions including detoxification, bile secretion, glycogen storage, immune defenses etc. What's more, kidney is an important excretory organ. The Function of liver and kidney indicator the toxicity of drugs ${ }^{24}$. The Function of liver and kidney is one of important indicator of toxicity ${ }^{24}$. As a sign of liver damage, oxidative stress causes multiple lesions in the plasma membrane ${ }^{25,26}$. One of the important targets of oxygen is glyceraldehyde-3-phosphate (GAPDH), which is also an important index of liver damage $\mathrm{e}^{27,28}$. The other important targets of liver damage are the changes of enzyme activity. AST and ALT are important enzymes in liver, both are vital to evaluate liver injury. ALT mainly exists in cytoplasm of liver cells, while AST in liver cytoplasm and mitochondria. Both ALT and AST will release into the blood when the liver cells are damaged. Cell degeneration, necrosis permeability of cell membranes or broken cell membrane increases in liver cells contained ALT and AST will be released into the blood, increased the activity of ALT and AST. Also, the concentration of BUN, CER and UA has been used to analyze the function of kidney, which will be changed when the tissues were damaged.

In previous reports, anti-tumor effects of 3BP in animals have been gradually found by the world ${ }^{29,30}$. The present study demonstrated that $8 \mathrm{mg} / \mathrm{kg}$ 3BP presented no hepatotoxicity and nephrotoxicity in nude mice, which also had a good effect of inhibiting tumor growth. For Kunming mice experiment, there was no significant hepatotoxicity in liver tissues for 3BP group (8mg/ $\mathrm{kg}$ ). In summary, these results may remind us that as a potent antitumor agent, 3BP has no hepatotoxicity and nephrotoxicity under the dose of inhibiting tumor cell growth. The extensive toxicity of 3BP need to be evaluated in further researches. The results of this study may have an implication for future study of 3BP.

\section{Conclusion}

3-Bromopyruvate at the dose of suppressing tumor growth did not exhibit hepatotoxicity and nephrotoxicity in nude 
mice, and the effect on liver was confirmed in Kunming mice.

\section{References}

1. Warburg O. On the origin of cancer cells. Science. 1956;123(3191):309-14. PMID: 13298683.

2. Xian SL, Cao W, Zhang XD, Lu YF. 3-Bromopyruvate inhibits human gastric cancer tumor growth in nude mice via the inhibition of glycolysis. Oncology Letters. 2015;9(2):739-44. PMID: 25621044.

3. Pedersen PL. 3-Bromopyruvate (3BP) a fast acting, promising, powerful, specific, and effective "small molecule" anti-cancer agent taken from labside to bedside: introduction to a special issue. $\mathrm{J}$ Bioenerg Biomembr. 2012;44(1):1-6. PMID: 22382780.

4. Tomizawa M, Shinozaki F, Motoyoshi Y, Sugiyama T, Yamamoto $\mathrm{S}$, Ishige N. Suppressive effects of 3-bromopyruvate on the proliferation and the motility of hepatocellular carcinoma cells. Oncol Rep. 2016;35(1):59-63. PMID: 26530887.

5. Wu L, Xu J, Yuan W, Wu B, Wang H, Liu G, Wang X, Du J, Cai $\mathrm{S}$. The reversal effects of 3-bromopyruvate on multidrug resistance in vitro and in vivo derived from human breast MCF-7/ADR cells. PloS one. 2014;9(11):e112132. PMID: 25372840.

6. Liu Z, Sun Y, Hong H, Zhao S, Zou X, Ma R, Jiang C, Wang Z, Li H, Liu H. 3-bromopyruvate enhanced daunorubicin-induced cytotoxicity involved in monocarboxylate transporter 1 in breast cancer cells. Am J Cancer Res. 2015;5(9):2673-85. PMID: 26609475.

7. Vali M, Liapi E, Kowalski J, Hong K, Khwaja A, Torbenson MS, Georgiades C, Geschwind JF. Intraarterial therapy with a new potent inhibitor of tumor metabolism (3-bromopyruvate): identification of therapeutic dose and method of injection in an animal model of liver cancer. J Vasc Interv Radiol. 2007;18(1 Pt 1):95-101. PMID: 17296709

8. Vossen JA, Buijs M, Syed L, Kutiyanwala F, Kutiyanwala M, Geschwind JF, Vali M. Development of a new orthotopic animal model of metastatic liver cancer in the rabbit VX2 model: effect on metastases after partial hepatectomy, intra-arterial treatment with 3-bromopyruvate and chemoembolization. Clin Exp Metastasis. 2008;25(7):811-7. PMID: 18649116.

9. Schaefer NG, Geschwind JF, Engles J, Buchanan JW, Wahl RL. Systemic administration of 3-bromopyruvate in treating disseminated aggressive lymphoma. Translational research. J Lab Clin Med. 2012;159(1):51-7. PMID: 22153810.

10. Zhang Q, Pan J, North PE, Yang S, Lubet RA, Wang Y, You M. Aerosolized 3-bromopyruvate inhibits lung tumorigenesis without causing liver toxicity. Cancer Prev Res (Phila). 2012;5(5):717-25. PMID: 22401980.

11. Ota S, Geschwind JF, Buijs M, Wijlemans JW, Kwak BK, Ganapathy-Kanniappan S. Ultrasound-guided direct delivery of 3-bromopyruvate blocks tumor progression in an orthotopic mouse model of human pancreatic cancer. Targeted Oncol. 2013;8(2):14551. PMID: 23529644.

12. Chapiro J, Sur S, Savic LJ, Ganapathy-Kanniappan S, Reyes J, Duran R, Thiruganasambandam SC, Moats CR, Lin M, Luo W, Tran PT, Herman JM, Semenza GL, Ewald AJ, Vogelstein B, Geschwind JF. Systemic delivery of microencapsulated 3-bromopyruvate for the therapy of pancreatic cancer. Clin Cancer Res. 2014;20(24):640617. PMID: 25326230.

13. Wang TA, Zhang XD, Guo XY, Xian SL, Lu YF. 3-Bromopyruvate and sodium citrate target glycolysis, suppress survivin, and induce mitochondrial-mediated apoptosis in gastric cancer cells and inhibit gastric orthotopic transplantation tumor growth. Oncol Rep. 2016;35(3):1287-96. PMID: 26708213.

14. Sun Y, Liu Z, Zou X, Lan Y, Sun X, Wang X, Zhao S, Jiang C, Liu $\mathrm{H}$. Mechanisms underlying 3-bromopyruvate-induced cell death in colon cancer. J Bioenerg Biomembr. 2015;47(4):319-29. PMID: 26054380.

15. Glick M, Biddle P, Jantzi J, Weaver S, Schirch D. The antitumor agent 3-bromopyruvate has a short half-life at physiological conditions. Biochem Biophys Res Commun. 2014;452(1):170-3. PMID: 26054380.

16. Shoshan MC. 3-Bromopyruvate: targets and outcomes. J Bioenerg Biomembr. 2012;44(1):7-15. PMID: 22298255.

17. Zhang Q, Zhang Y, Zhang P, Chao Z, Xia F, Jiang C, Zhang X, Jiang Z, Liu H. Hexokinase II inhibitor, 3-BrPA induced autophagy by stimulating ROS formation in human breast cancer cells. Genes Cancer. 2014;5(3-4):100-12. PMID: 25053988.

18. Liu Z, Zhang YY, Zhang QW, Zhao SR, Wu CZ, Cheng X, Jiang CC, Jiang ZW, Liu H. 3-Bromopyruvate induces apoptosis in breast cancer cells by downregulating Mcl-1 through the PI3K/ Akt signaling pathway. Anticancer Drugs. 2014;25(4):447-55. PMID: 24492287.

19. Mayuren C, Reddy VV, Priya SV, Devi VA. Protective effect of Livactine against $\mathrm{CCl}(4)$ and paracetamol induced hepatotoxicity in adult Wistar rats. North Am J Med Sci. 2010;2(10):491-5. PMID: 22558553.

20. Straka C, Hebart H, Adler-Reichel S, Werding N, Emmerich B, Einsele H. Blood stem cell collections after mobilization with combination chemotherapy containing ifosfamide followed by G-CSF in multiple myeloma. Oncology. 2003;65 Suppl 2:94-8. PMID: 14586157.

21. Skinner R, Pearson AD, English MW, Price L, Wyllie RA, Coulthard MG, Craft AW. Risk factors for ifosfamide nephrotoxicity in children. Lancet. 1996;348(9027):578-80. PMID: 8774570.

22. Lionel AP, Chinnaswamy G, John RR, Mathai S. Ifosfamide induced renal rickets. Indian J Pediatr. 2014;81(9):943-5. PMID: 23912821.

23. Geschwind JF, Ko YH, Torbenson MS, Magee C, Pedersen PL. Novel therapy for liver cancer: direct intraarterial injection of a potent inhibitor of ATP production. Cancer Res. 2002;62(14):390913. PMID: 12124317.

24. Liu J, Shi JZ, Yu LM, Goyer RA, Waalkes MP. Mercury in traditional medicines: is cinnabar toxicologically similar to common mercurials? Exp Biol Med (Maywood). 2008;233(7):810-7. PMID: 18445765.

25. Wu FL, Liu WY, Van Poucke S, Braddock M, Jin WM, Xiao J, Li XK, Zheng MH. Targeting endoplasmic reticulum stress in liver disease. Expert Rev Gastroenterol Hepatol. 2016. PMID: 27093595.

26. Blas-Garcia A, Apostolova N, Valls-Belles V, Esplugues JV. Endoplasmic reticulum and mitochondria: independent roles and crosstalk in fatty liver diseases and hepatic inflammation. Curr Pharm Des. 2016;22(18):2607-18. PMID: 26845326.

27. Hara MR, Cascio MB, Sawa A. GAPDH as a sensor of NO stress. Bioch Biophys Acta. 2006;1762(5):502-9. PMID: 16574384.

28. Chen RW, Saunders PA, Wei H, Li Z, Seth P, Chuang DM. Involvement of glyceraldehyde-3-phosphate dehydrogenase $($ GAPDH) and p53 in neuronal apoptosis: evidence that GAPDH is upregulated by p53. J Neurosc. 1999;19(21):9654-62. PMID: 10531467.

29. Cardaci S, Desideri E, Ciriolo MR. Targeting aerobic glycolysis: 3-bromopyruvate as a promising anticancer drug. J Bioenerg Biomembr. 2012;44(1):17-29. PMID: 22328057. 
30. Chen Z, Zhang H, Lu W, Huang P. Role of mitochondria-associated hexokinase II in cancer cell death induced by 3-bromopyruvate. Biochim Biophys Acta. 2009;1787(5):553-60. PMID: 19285479.

\section{Correspondence:}

Hao Liu

Bengbu Medical College, Anhui - China

Phone: +865523175230

Fax: +865523175234

liuhao6886@foxmail.com

Received: July 03, 2016

Review: Sep 08, 2016

Accepted: Oct 10, 2016

Conflict of interest: none

Financial sources: The National Science Foundation of China $\left(\mathrm{n}^{\circ}\right.$ 81372899), The Provincial Science and Technology Cooperation Project of Anhui province $\left(\mathrm{n}^{\mathrm{o}}\right.$ 1503062024), The Natural Science Foundation of Anhui province ( $\mathrm{n}^{\mathrm{o}}$ 1508085MH166), and University Natural Science Project of Anhui Province ( $\mathrm{n}^{\circ}$ KJ2016A486).

${ }^{1}$ Research performed at Engineering Technology Research Center, Bengbu, China. 